\title{
PENDEKATAN LINGUISTIK SINKRONIS DAN DIAKRONIS PADA BEBERAPA DIALEK MELAYU: PEMIKIRAN KRITIS ATAS SEJARAH BAHASA MELAYU
}

\author{
Restu Sukesti \\ Balai Bahasa Yogyakarta \\ Korespondensi: J1. I Dewa Nyoman Oka 34 Yogyakarta \\ Pos-el: restu_sukesti@yahoo.co.id
}

\begin{abstract}
Abstrak
Perdebatan tentang asal usul bahasa Indonesia masih terus berlangsung. Untuk membuktikan pendapat mana yang paling tepat, haruslah dibuktikan secara ilmiah akademik. Untuk menjawab masalah itu, tulisan ini berupaya untuk menganalisis asal bahasa Melayu yang menjadi cikal bakal bahasa Indonesia secara linguistik. Caranya ialah membandingkan bahasa Indonesia dengan dialek Malayu Menado dan Melayu Ambon, yang dianalisis secara sinkronis dan diakronis. Dalam penganalisisan itu digunakan metode distribusional dengan membandingkan bahasa Indonesia dengan dialek Melayu Menado dan dialek Melayu Ambon. Hal yang diperbandingkan dalam domain sinkronis ialah aspek fonologis, morfologis, dan sintaktis; dalam domain diakronis ialah aspek linguistik dan aspek ekstralinguistik. Hasil yang diperoleh ialah bahasa Melayu yang menjadi cikal bakal bahasa Indonesia bukan merupakan dialek Melayu. Dengan demikian, hasil penelitian ini diharapkan dapat memperkuat jati diri bahasa Indonesia, baik dari segi linguistik maupun politik.
\end{abstract}

Kata-kata kunci : sinkronis, diakronis, dialek, pijin, kreol

\begin{abstract}
The debate about the origin of Indonesian is still ongoing. To prove the most appropriate statement, the statement must be tested academic scientifically. To answer that problem, this paper seeks to analyze the origin of the Malay language that becomes the forerunner Indonesian language linguistically. The analysis is carried out by comparing Indonesian language with Manado Malay dialect and Malay Ambon, which is analyzed synchronically and diachronically. In analyzing that problem, the distributional method is used to compare the Indonesian with Manado Malay dialect and Ambonese Malay dialect. The comparability in synchronous domain is phonological, morphological, and syntactic aspects; in diachronic domain linguistic and extra-linguistic aspects are compared. The results obtained is Malay language becomes the forerunner of Indonesian and it is not a Malay dialect. Thus, the results of this study are expected to strengthen Indonesian language identity, both in terms of linguistic and political aspect.
\end{abstract}

Keywords: Synchronic, diachronic, dialect, pidgin, creole

\section{PENDAHULUAN}

Bahasa Indonesia bukan bahasa yang lahir secara alamiah, melainkan hasil kesepakatan sosiologis dan politis, yaitu pengangkatan bahasa Melayu menjadi bahasa Indonesia. Namun, asal-usul bahasa Indonesia yang berasal dari bahasa Melayu itu sering diperdebatkan. Perdebatan itu berkisar pada bahasa Melayu manakah yang menjadi cikal bakal bahasa Indonesia. Sejumlah ahli bahasa menyatakan 
bahwa bahasa Indonesia berasal dari bahasa Melayu yang digunakan di Semenanjung Malaka, dan ada yang menyatakan bahwa bahasa Indonesia berasal dari bahasa Melayu Tinggi yang digunakan di Riau dan di Jakarta.

Berdasarkan banyaknya pendapat tentang sejarah bahasa Indonesia, perlu diadakan penelitian akademik yang komprehensif tentang asal bahasa Indonesia. Penelitian itu, seyogianya dilakukan secara linguistis dengan pendekatan secara diakronis dan sinkronis. Pendekatan diakronis dilakukan untuk melihat perjalanan bahasa Indonesia secara linguistik historis; pendekatan sinkronis dilakukan untuk melihat keadaan bahasa Indonesia jika dibandingkan dengan bahasa Melayu (dialek Melayu) yang ada saat ini. Keduanya dilakukan untuk memaksimalkan pengatasan masalah yang ada tentang sejarah bahasa Indonesia. Dan, penelitian itu perlu dilakukan untuk menegakkan sejarah bahasa Indonesia sehingga dapat bermanfaat dalam bidang linguistik, historik, dan politik.

Sementara itu, banyak pendapat yang menyatakan bahwa bahasa Indonesia merupakan pijin, kreol, atau bukan pijin maupun kreol. Untuk itu, sebagai langkah awal pembicaraan tentang "bentuk" bahasa Indonesia yang apakah merupakan pijin atau merupakan kreol, atau bukan keduanya, perlu dibicarakan dahulu tentang apa yang dimaksud dengan pijin dan kreol. Pijin ialah suatu bahasa campuran dari dua bahasa (atau lebih) yang muncul secara alamiah karena masing-masing pihak penutur bahasa aslinya tidak saling mengerti (Wardhaugh, 1986:57; Fasold, 1990:181; Crystal, 1992:334). Tentu saja, pijin itu tercipta agar masing-masing pihak dapat saling berkomunikasi. Biasanya, bahasa pijin terjadi dari bahasa penduduk asli yang bercampur dengan bahasa kaum pendatang. Biasanya pula, "sumbangan" dari bahasa penduduk asli lebih banyak daripada "sumbangan" dari bahasa kaum pendatang, tetapi hal itu tidak bersifat mutlak. Yang terpenting ialah bahasa pijin lebih sederhana dari masing-masing bahasa "penyumbangnya". Dengan kata lain, bagian mana yang lebih mudah diterima/dimengerti oleh kedua belah pihak, bagian itu pula yang masuk ke dalam pijin.

Selain itu, pijin juga dapat muncul pada daerah yang dihuni oleh orang-orang sesama pendatang di suatu tempat yang masing-masing memiliki bahasa ibu berlainan, yang di antara mereka tidak dapat saling memahami bahasa ibu pihak lain. Untuk itu, mereka menggunakan, misalnya, bahasa Inggris (sebagai bahasa internasional) yang juga sebenarnya tidak mereka pahami sepenuhnya. Akhirnya, bahasa yang muncul secara spontan ialah bahasa Inggris bercampur dengan kedua bahasa ibu mereka sehingga terbentuklah bahasa pijin Inggris (Wardhaugh, 1986:58-75).

Pijin, jelas-jelas bukan merupakan bahasa ibu bagi para penuturnya. Namun, pijin itu dapat sebagai lingua franca (alat komunikasi), yaitu secara luas digunakan masyarakat yang masing-masing memiliki bahasa ibu yang berbeda. Sebagai lingua franca, pijin tersebut digunakan dalam kurun waktu yang relatif lama dari generasi ke generasi sehingga memungkinkan pijin itu menjadi bahasa ibu bagi generasi berikutnya. Pijin yang sudah menjadi bahasa ibu bagi para penuturnya itu disebut kreol. Dengan demikian kreol ialah pijin yang sudah memiliki penutur asli (Todd, 1974:52; Wardhaugh, 1986:76; Fasold, 1990:186; Crystal, 1992:336). Untuk 
memperjelas tentang pijin dan kreol, dapat dilihat diagram berikut.

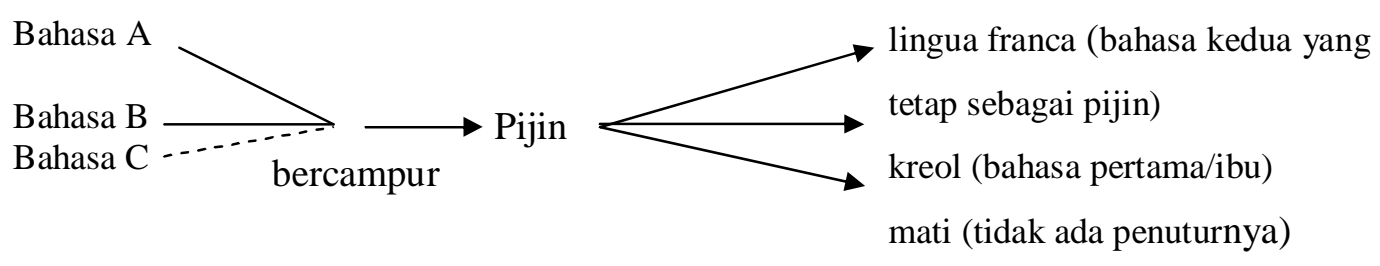

Diagram 1. Pijin dan kreol

Terdapat sejumlah ahli yang menganggap bahwa bahasa Indonesia merupakan pijin, yaitu, antara lain, G.M. Kahin (1952), R.A. Hall (ahli pijin dan kreol) (1976), Hopper (1972), Poedjosoedarmo (1978), dan Chaedar Alwasilah (1985) dalam Chaer, Abdul dan Leonie Augustina, 1995:302). Pendapat itu ditentang oleh Kridalaksana (1991). Dikatakan olehnya bahwa bahasa Indonesia bukan berasal dari bahasa Melayu Bazaar (Melayu Pasar/Rendah), melainkan berasal dari bahasa Melayu Tinggi yang berpusat di Riau dan Johor. Dan, bahasa Melayu Tinggi pada waktu itu sudah memiliki vitalitas (penutur asli), historitas, dan otonomi (keaslian), yang semuanya itu bukan cirri jenis pijin. Di pihak lain, pada waktu itu bahasa Melayu pasar tidak memiliki vitalitas, otonomi dan historitas, hanya sebagai lingua franca saja. Bahasa Melayu Pasar merupakan bahasa campuran (pijin) yang menyebar ke sebagian wilayah Indonesia yang pada akhirnya menjadi kreol dengan sebutan, misalnya, dialek Melayu Ambon, Melayu Jakarta, Melayu Banjar, Melayu Loloan, dan sebagainya, bukan sebagai bahasa Indonesia yang standar. Dipihak lain, bahasa Melayu Tinggi yang berpusat di Riau menyebar ke
Jakarta yang kemudian digunakan sebagai bahasa pengantar pendidikan pada waktu itu. Bentuk bahasa Melayu Tinggi tersebut (yang digunakan dalam dunia pendidikan) sangat berbeda dengan bahasa Melayu Pasar yang menjadi lingua franca di Jakarta (yang akhirnya menjadi kreol dialek Melayu Jakarta). Dengan itu, jelas-jelas Kridalaksana membedakan antara keberadaan bahasa Melayu Tinggi dan Melayu Pasar (Chaer, A, dan Agusta, L, 1995).

Wardhaugh sedikit menyinggung tentang "status" bahasa Indonesia yang diyakininya sebagai kreol. Namun, dia mempertanyakan apakah kekreolan itu disebabkan oleh adanya upaya standardisasi bahasa Indonesia, bukan oleh adanya penutur asli bahasa Indonesia (1986:83-84).

Dengan adanya pendapat beberapa ahli tentang penjenisan bahasa Indonesia tersebut, dapat digolongkannya tiga hipotesis tentang penjenisan bahasa Indonesia, yaitu: (1) bahasa Indonesia merupakan pijin (belum kreol), (2) bahasa Indonesia merupakan kreol, dan (3) bahasa Indonesia bukan merupakan pijin ataupun kreol. Untuk memperjelas masalah itu, berikut bagan ketiga hipotesis tersebut. 
bahasa \& sastra, Vol.15, No.1, April 2015

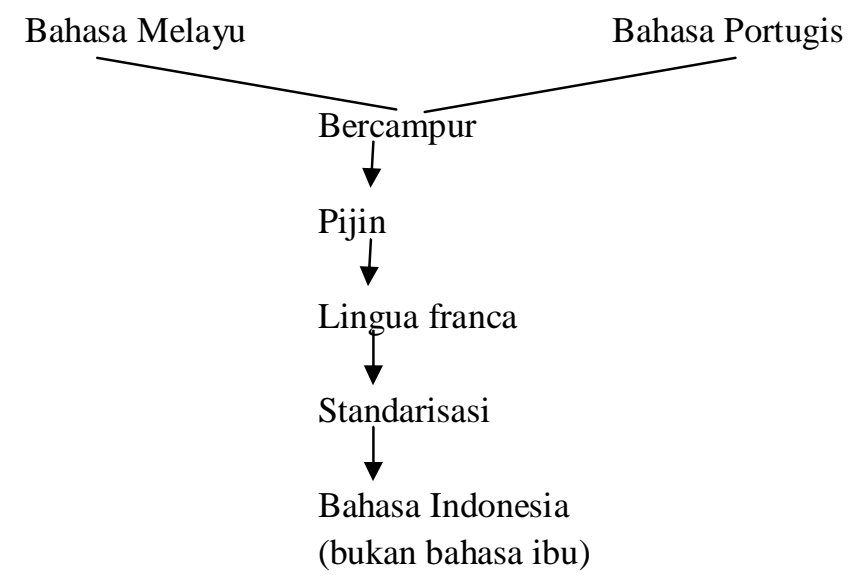

Diagram 2. Hipotesis 1: Bahasa Indonesia Merupakan Pijin

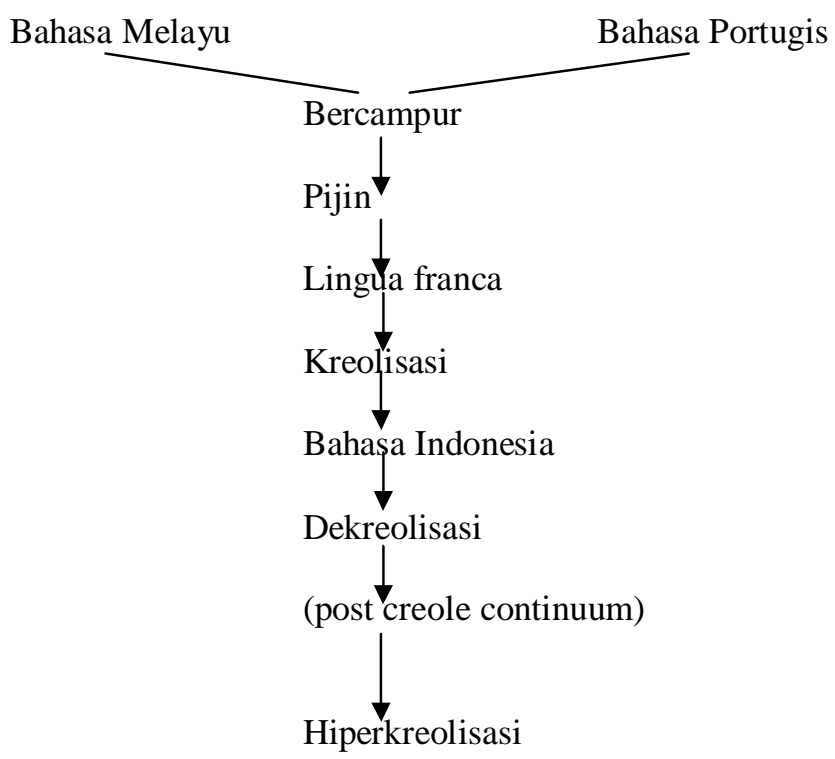

Diagram 3: Hipotesis 2: Bahasa Indonesia Merupakan Kreol 


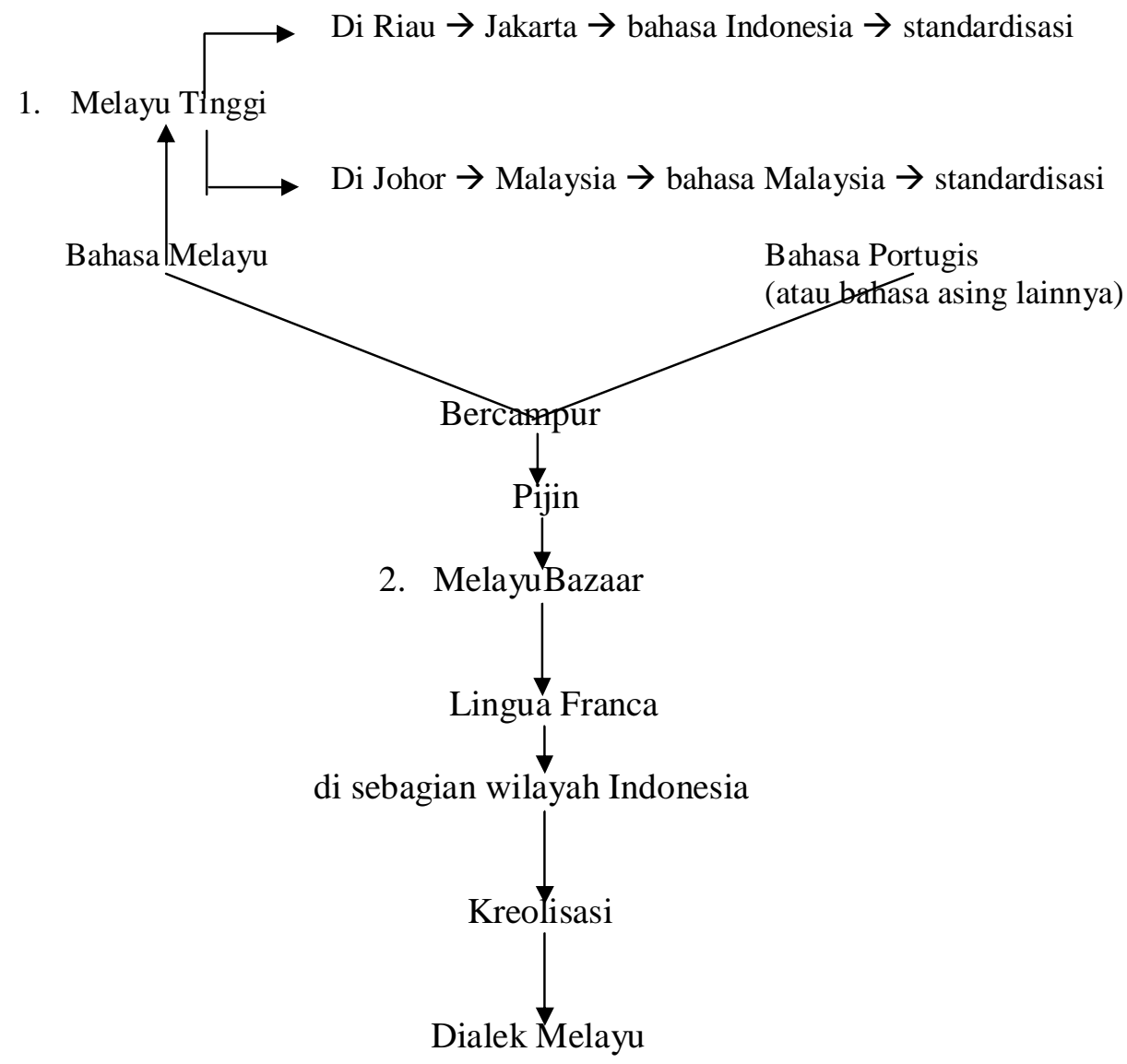

Diagram 3. Hipotesis 3: Bahasa Indonesia Bukan Pijin ataupun Kreol

Selain Kridalaksana, terdapat beberapa ahli yang menyatakan bahwa bahasa Melayu memiliki dua varian, yaitu Melayu Tinggi dan Melayu Pasar. Ahli tersebut ialah, antara lain, Valentijn (yang membaginya menjadi Melayu Tinggi dan Melayu Pasar), Marsden (yang membaginya menjadi Melayu Tinggi (Melayu Dalam dan Bangsawan) dan Melayu Rendah (Melayu Dagang dan Melayu Kucukan), Dulaurier (yang membaginya menjadi Melayu literer/buku dan Melayu sehari-hari) dan Werndly (yang juga membaginya menjadi Melayu Tinggi dan Melayu Rendah). Namun, mereka tidak menyatakan lebih jauh tentang bagaimana perubahan bahasa Melayu tersebut menjadi bahasa Indonesia (Alisjahbana, 1975:21-53). Di pihak lain,
Alisjahbana (1978) menyatakan bahwa bahasa Indonesia berasal dari bahasa Melayu, tetapi tidak menjelaskan bahasa Melayu yang mana sebagai asal bahasa Indonesia, apalagi tentang jenis bahasa Melayu atau Indonesia sebagai sebuah pijin, kreol, atau bukan keduanya.

Dalam penelitian ini dibahas tentang bahasa Indonesia dilihat sebagai bentuk pijin, kreol, atau bukan kedua-duanya. Seandainya bukan kedua-duanya, berarti bahasa Indonesia sebagai bentuk lain, misalnya bentuk standar. Untuk itu, Stewart (1968 dalam Suhardi 1995) telah membuat suatu kriteria penjenisan bahasa seperti berikut. 
Tabel 1. Kriteria Penjenisan Bahasa

\begin{tabular}{|c|c|c|c|l|}
\hline \multicolumn{5}{|c|}{ Dasar Penjenisan } \\
\cline { 1 - 3 } Historitas & Standarisasi & Vitalitas & Otonomi & \\
\cline { 1 - 3 }+ & + & + & + & Standar \\
+ & + & -- & + & Klasik \\
+ & -- & + & + & Vernakular \\
-- & -- & + & + & Kreol \\
-- & -- & - & -- & Pijin \\
-- & + & -- & + & Artifisial \\
+ & -- & + & -- & Dialek \\
\hline
\end{tabular}

(Sumber: Suhardi, B., et al. (1995)

Penelitian ini berupaya menjawab apakah sebenarnya bahasa Indonesia merupakan pijin atau bukan. Untuk itu, dalam tulisan ini akan dipaparkan bukti-bukti linguistik diakronis dan sinkronis serat bukti nonlinguistik untuk mendukung keakuratan asal bahasa Indonesia. Hasil dari pembuktian itu diharapkan dapat bermanfaat untuk kepentingan pengajaran sejarah bahasa Indonesia, pengayaan kajian linguistik Indonesia, dan untuk pengukuhan jati diri bahasa Indonesia.

\section{METODE}

Dalam penelitian ini, peneliti berupaya untuk mengkaji apakah bahasa Indonesia merupakan (berasal dari) pijin Melayu atau tidak. Untuk itu, sebagai pengetesan, perlu diadakan penelitian secara sinkronis dan diakronis tentang bahasa Indonesia itu sendiri. Yang dimaksud dengan penelitian sinkronis di sini ialah melihat perbandingan antara bahasa Indonesia dan dialek-dialek Melayu yang ada, hanya dalam makalah yang masih sederhana ini dicoba dibandingkan bahasa Indonesia dengan dialek Melayu Menado dan Melayu Ambon. Yang dimaksud dengan penelitian diakronis ialah

melihat perbandingan/perkembangan bahasa Indonesia yang sekarang dari Bahasa Melayu (Tinggi) secara top down dengan memanfaatkan karya sastra yang ada. Untuk itu, metodologi analisis data yang digunakan ialah metode padan intralingual dan ekstralingual (Mahsun, 2005:117124). Dalam tulisan ini, untuk kajian sinkronis dimanfaatkan teknis analisis perbandingan antarbahasa pada tiga bahasa (dialek) dalam bentuk fonologis, morfologis, dan sintaktik; untuk kajian diakronis dimanfaatkan teknis perbandingan bahasa lama dengan bahasa Indonesia (standar).

\section{HASIL DAN PEMBAHASAN}

Telah disebut dalam pembahasan sebelumnya bahwa ada tiga hipotesis tentang jenis bahasa Indonesia, yaitu sebagai pijin, sebagai kreol, dan bukan sebagai pijin ataupun kreol. Untuk itu, tampaknya perlu adanya kesepakatan tentang hipotesis mana yang paling benar. Dan untuk mendapatkan kebenaran hipotesisnya perlu diadakan penelitian. Oleh karena itu, dalam makalah ini penulis menentukan hipotesis 3-lah yang dapat dicarikan bukti-bukti yang kuat.

Bukti untuk mendukung hipotesis bahwa bahasa Indonesia bukan merupakan pijin ataupun kreol 
ialah bukti intralinguistik dan ekstralinguistik. Yang dimaksud dengan bukti intralinguistik ialah adanya evidensi linguistis (aspek fonologis, morfologis, dan sintaksis) yang memperkuat dugaan bahwa bahasa Indonesia berasal dari bahasa Melayu Tinggi, bukan dari Melayu Pasar. Yang dimaksud dengan bukti ekstralinguistik ialah adanya evidensi di luar kebahasaan (historis, sosiologis, dan literer) yang dapat mendukung hipotesis yang ada. Untuk itu, berikut penjabaran tentang pembuktian bahwa bahasa Indonesia bukan merupakan pijin ataupun kreol.

Dardjowidjojo

(1996:78-86)

mengatakan bahwa (bahasa) pijin Melayu memiliki persyaratan di antaranya: (1) tidak berafiks, untuk penggantinya digunakan kata bantu, (2) penunjukan posesif menggunakan kata punya, (3) kata lagi tidak hanya bermakna pengulangan, tetapi juga bermakna 'masih, pula, juga', (4) adanya penyederhanaan bentuk, termasuk lenisi bunyi, (5) adanya pengaruh bahasa-bahasa di Eropa dalam tataran sintaksisnya.
Di pihak lain, linguistik memiliki aspek fonologis, morfologis, sintaktis, dan semantik. Tampaknya, semua aspek tersebut menjadi pembeda antara pijin Melayu (dialek Melayu) dan bahasa Indonesia, kecuali aspek semantik karena perbedaan makna tidak dapat sebagai alat pembeda antara pijin Melayu dan bahasa Indonesia. Berikut ini peneliti paparkan pembuktian linguistik sinkronis dan diakronis.

\section{Pembuktian secara Sinkronis}

Pembuktian secara sinkronis dilakukan dengan memanfaatkan bukti perbedaan fonologis, morfologis, dan sintaktis.

\subsection{Bukti Fonologis}

Dalam dialek Melayu, misalnya Melayu Menado (Dardjowidjojo, 1996) dan Melayu Ambon (Rona, 1999) banyak ditemukan penyederhanaan bentuk fonologisnya. Penyederhanaan itu dapat berupa lenisi apokop (penghilangan bunyi pada akhir kata). Karena itu, jika dibandingkan dengan bahasa Indonesia, keduanya akan berbeda, misalnya:

Bahasa Indonesia
kasih
dapat
ingat
taruh
penuh

Selain apokop, juga terjadi perubahan secara kontraksi yang membedakan

dialek Melayu Menado
kase
dapa
inga

\author{
dialek Melayu Ambon \\ dapa \\ taro \\ pono
}

dialek Melayu Menado
deng
pi
lei

dialek Melayu dengan bahasa Indonesia, misalnya:

Bahasa Indonesia
dengan
pergi
lagi
punya

Bahasa Indonesia dialek Melayu Ambon

pung 


Bahasa Indonesia
$\partial$ nam
b $\partial$ nci
t $\partial$ man
k $\partial$ liling

Bunyi / $\partial$ / tidak dapat muncul pada awal kata pada dialek Melayu
Menado, bahkan bunyi itu hilang pada dialek Melayu Ambon, misalnya:

\subsection{Bukti Morfologis}

Peniadaan afiks pada bentuk kata juga banyak terjadi dalam penurunan bahasa Melayu ke dialek

\author{
dialek Melayu Menado \\ anam \\ banci
}

tamang

kuliling

\section{Bahasa Indonesia \\ dipukul \\ menjatuhkan \\ berbalasan}

\author{
dialek Melayu Menado \\ dapa pukul \\ kase jatuh \\ baku balas
}

Melayu (contohnya dialek Melayu Menado dan Melayu Ambon). Karena itu, jika dibandingkan dengan bahasa Indonesia akan jauh berbeda, misalnya:

\subsection{Bukti Sintaksis}

Dalam tataran sintaksis dibicarakan tentang bentuk frasa dan klausa. Namun, perubahan bentuk klausa tidak dapat dideteksi dengan baik karena dialek Melayu tidak mempunyai tradisi literer, sedangkan bahasa Melayu mempunyai wujud teks literer sehingga yang tampak di antara keduanya ialah perubahan dalam bentuk frasa.

\author{
dialek Melayu Menado \\ kita punya mulut \\ dia punya rumah
}

\section{dialek Melayu Ambon}

\begin{abstract}
Frasa dalam dialek Melayu banyak yang berubah/berbeda dari bahasa Melayu, misalnya bentuk frase posesif. Dalam bahasa Melayu berbentuk nomina + pronomina milik dalam dialek Melayu berubah menjadi pemilik + partikel posesif + termilik. Hal itu dipengaruhi oleh sistem bahasa di Eropa, yaitu penggunaan kata belong. Oleh karena itu, jika dibandingkan dengan bahasa Indonesia, keduanya akan berbeda, misalnya:
\end{abstract}

Pembuktian adanya perbedaan tersebut dapat memperkuat hipotesis bahwa bahasa Indonesia berbeda dengan dialek-dialek Melayu yang digunakan di beberapa wilayah di Indonesia meskipun keduanya berakar dari bahasa yang sama, yaitu bahasa Melayu. Hanya, bahasa Indonesia berakar dari bahasa Melayu yang bukan merupakan bahasa campuran, yang disebut bahasa Melayu Tinggi, sedangkan dialek Melayu berakar dari bahasa Melayu Pasar yang merupakan bahasa campuran dari beberapa bahasa. Selain itu, perlu juga dilihat apakah bahasa Melayu Pasar itu juga benarbenar sebagai pijin.

Sebenarnya, penelitian tentang perbandingan bahasa Indonesia dengan dialek-dialek Melayu dapat dilakukan secara komprehensif, yaitu dengan membandingkan bahasa Indonesia dengan dialek-dialek Melayu yang lain yang ada di Indonesia. Selain itu, dapat 
pula dimanfaatkannya beberapa hasil penelitian yang sudah dilakukan oleh para ahli bahasa dan yang sudah diuji kesahihannya. Di samping itu, bahasa Indonesia itu sendiri perlu dilihat isinya, apakah sudah merupakan sebuah bahasa campuran (meskipun asalnya dari bahasa Melayu Tinggi yang bukan berupa bahasa campuran). Hal itu dapat saja terjadi karena perkembangan bahasa Indonesia itu sendiri. Dan, apakah campuran itu hanya berupa interferensi atau hanya berupa integrasi.Analisis tersebut harus dipertimbangkan pula dengan prinsipprinsip terjadinya pijin.

\section{Pembuktian Secara Diakronis}

Pembuktian secara diakronis berarti melihat perbandingan bahasa, dalam hal ini ialah bahasa Indonesia, dalam suatu kurun waktu ke kurun waktu yang lain. Karena yang akan dilihat ialah asal mula bahasa Indonesia, berarti yang dilihat ialah perbandingan keadaan bahasa Indonesia yang sekarang dengan bahasa Indonesia yang terdahulu dan dengan bahasa Melayu Tinggi maupun dengan bahasa Melayu Pasar, dengan metode top down. Sayangnya, bukti tertulis pada bahasa Melayu Pasar tidak ada (hal itu menunjukkan bahwa bahasa Melayu Pasar hanya merupakan pijin) sehingga hanya bisa dengan bukti tertulis pada bahasa Melayu Tinggi (hal itu menunjukkan bahwa Bahasa Melayu Tinggi bukan pijin). Bukti tertulis dalam Melayu Tinggi yang bisa dilacak ialah adanya karya-karya sastra yang terbit dalam bahasa Melayu. Karena perbandingan itu berupa bahasa tulis, aspek fonetisnya tidak dapat diperbandingkan, hanya aspek morfologis dan sintaktis yang dapat diperbandingkan. Untuk itu, berikut adalah contoh perbandingannya. Perbandingan itu dilakukan secara top down, yaitu melihat perkembangan bahasa Indonesia dengan cara merunut bukti kebahasaan dari masa kini ke masa dahulu. Untuk itu, akan ditunjukkan bukti karya sastra dari angkatan Balai Pustaka, sastra lama akhir abad ke-19, abad ke-17, dan abad ke-16.

Kutipan dari novel Siti Nurbaya karya Marah Rusli (1965):

$$
\begin{aligned}
& \text { Tatkala itu datanglah Puteri } \\
& \text { Rukiyah membawa suatu } \\
& \text { hidangan, jang berisi } \\
& \text { semangkuk kopi dan kue-kue, } \\
& \text { kehadapan Sutan Mahmud, lalu } \\
& \text { diletakannja diatas medja. } \\
& \text { Kemudian masuklah ia } \\
& \text { kedalam biliknja. Rupanja ia } \\
& \text { mengerti, bahwa orangtuanja } \\
& \text { itu sedang memperbintjan hal } \\
& \text { jang tidak boleh didengarnja, } \\
& \text { sebab ketika ia sampai kesana, } \\
& \text { tiba-tiba kedua mereka } \\
& \text { berhenti sedjurus berkata-kata. } \\
& \text { Tetapi ada djuga didengarnja } \\
& \text { namanya disebut. "Barangkali } \\
& \text { mereka memperbintjang } \\
& \text { perkara perkawinanku," pikir } \\
& \text { puteri Rukijah dalam hatinja, } \\
& \text { sebagai hendak melenjapkan } \\
& \text { pikiran jang demikian: "Ah tak } \\
& \text { lajak bagi seorang anak } \\
& \text { perawan, memikirkan hal itu." } \\
& \text { (hlm. 20) }
\end{aligned}
$$

Penggunaan bahasa Melayu dalam novel tersebut (1920-an) tidak jauh berbeda dengan penggunaan bahasa Indonesia saat ini, baik dalam bentuk morfologis maupun sintaktisnya. Dan, penggunaan bahasa tersebut berbeda dengan dialek-dialek Melayu yang ada di beberapa wilayah di Indonesia, yaitu aspek morfologis (afiks), bentuk posesif, dan aspek sintaktisnya.

Berikut kutipan dari karya sastra lama abad akhir ke-19 Hikayat 


\section{Nahkoda Asik karya Sabirin Bin Usman (suntingan Henri Chambert-Loir, 2009).}

Hatta maka adalah berapa lamanya Baginda duduk kedua laki istri dalam kerajaannya maka di dalam masa zamannya, Baginda datang pikiranya yang amat masgul berduka cita daripada sebab ia dalam kerajaanya tiada sekalikali ada mempunyai putra, ingin rasanya mendapat putra laki-laki yang bijaksana dan yang alim lagi budiman. Suatu hari baginda dihadap dengan istrinya duduk berjejer dengan beberapa inang pengasuh dan beberapa pula menteri dan hulubalang, maka kata baginda, "Ya Adinda Asma Pengasih, apalah pula jika datang suatu masa dilakukan oleh Tuhan Malik al-Qahhar, siapak yang dapat menggantikan duduk kerajaan kakanda ini karena anak pun tiada dan pengganti yang patut pun tiada .... (hlm. 14)

Berikut kutipan dari karya sastra lama abad ke-17 Bustan al-Salatin (suntingan Siti Hawa Haji Salleh, 1992, Dewan Bahasa dan Pustaka, Kementrian Pendidikan Malaysia, Kuala Lumpur)

Kemudian dari itu maka kerajaan Sultan Alauddin Riayat Syah ibn Sultan Ali Mughayat Syah, pada hari Isnin, waktu duha, dua puluh hari bulan Zulkaedah. Ialah yang mengadatkan segala istiadat kerajaan Aceh Dar al-Salam dan mengutus utusan kepada Sultan Rum, ke negeri Istambul, kerana meneguhkan agama islam. Maka dikirim Sultan Rum daripada jenis utus dan pandai yang tahu menuang bedil. Maka pada zaman itulah dituang meriam yang besar-besar. Dan ialah yang pertama-tama berbuat kota di negeri Aceh Dar al-Salam, dan ialah yang pertama-tama ghazi dengan segala kafir, hingga sendirinya berangkat menyerang Melaka. .... (hlm. 2)

Berikut adalah kutipan dati karya sastra abad ke-16 Hikayat Muhammad Hanafiyyah (suntingan L.F. Brakel, 1975, Koninklijk Instituut Voor Taal-, Land- ed Volkenkunde, The Hague-Martinus Nijhoff).

Adapun pada sehari, bahwa
rasul Allah duduk dengan segala
sahabat, bahwa ada Dahyat al-
Kalbi, seorang daripada pihak
Bani Kilab, bahwa ia keluarga
Rasul Allah; barangkal ia
datang kepada rasul Allah, maka
rasul Allah memeri upacara
dengan hormatnya. Adapun
barangkali Dahyat al-Kalbi
datang kepada rasul Allah ada
jua suatu buah-buahan
dibawanya, karena amir Hasan
dan amir Husain, kedua orang
itu terlalu jinak kepada Dahyat
al-Kalbi:barang ada dibawa oleh
Dahyat al-Kalbi, maka diambil
oleh amir hasan dan amir
Husain. (hlm. 118)

Ketiga kutipan sastra lama tersebut masih menunjukkan kemiripan dengan bahasa Indonesia saat ini. Kemiripan itu tampak pada bentuk morfologis dan sintaktisnya. Aspek morfologis yang mirip dengan bahasa Indonesia saat ini ialah adanya afiks me-/-kan, me-/-i, -an, ber-, me-, dan ter; adanya bentuk ulang; adanya partikel lah, pun, dan adanya klitika nya. Aspek sintaktis yang mirip dengan bahasa Indonesia saat ini ialah adanya bentuk frasa yang berstruktur DM (misalnya 
orang itu, tempat pujaan itu, dan keluarga rasul Allah).

\section{Pembuktian Secara Ekstralinguistis}

Faktor ekstralinguistik juga dapat digunakan untuk membuktikan bahwa bahasa Indonesia bukan berasal dari bahasa Melayu Pasar, tetapi berasal dari Melayu Tinggi. Dan seperti yang kita ketahui, bahasa Melayu Pasar merupakan pijin, sedangkan bahasa Melalyu Tinggi bukan pijin. Faktor ekstralinguistik yang digunakan ialah faktor kesejarahan (bukti sejarah) dan faktor literer (bukti karya sastra).

\subsection{Bukti Sejarah}

Bahasa Melayu Tinggi yang digunakan di Riau termasuk bahasa yang berpretise karena digunakan oleh para bangsawan. Kemudian, oleh pemerintah Hindia Belanda yang menjajah Indonesia waktu itu membuat kebijakan bahwa bahasa Melayu tersebut digunakan sebagai pengantar pendidikan di wilayah jajahannya, terutama di Jakarta. Dengan itu, bahasa Melayu Tinggi digunakan oleh kaum terpelajar. Selanjutnya, pada tahun 1901 Van Ophuijen membuat ejaan bahasa Melayu yang termuat dalam Kitab Logat Melayoe yang tentu saja ejaan itu ejaan bahasa Melayu Tinggi, bukan Melayu Pasar yang waktu itu sudah menjadi lingua franca di sebagian besar wilayah Indonesia.

Para pemuda yang juga sebagai kaum pelajar mengadakan kongres pemuda pada tanggal 28 Oktober 1928 dengan salah satu keputusannya ialah "Menjunjung bahasa Persatuan yaitu bahasa Indonesia". Karena itu, selanjutnya, bahasa perpolitikan mereka ialah bahasa Indonesia yang tentu saja yang berasal dari Melayu Tinggi karena penggunanya ialah kaum terpelajar. Klimaksnya, bahasa Indonesia tersebut distandardisasikan secara resmi pada tanggal 18 Agustus 1945 sebagai bahasa persatuan dan bahasa negara. Di pihak lain bahasa Melayu Pasar semakin tumbuh subur, bahkan menjadi kreol di berbagai tempat, termasuk yang ada di Jakarta. Jadi, pada waktu itu di Jakarta (sebagai pusat Pemerintahan Belanda maupun Indonesia) memiliki dua bahasa, yaitu bahasa Melayu Tinggi yang secara politis menjadi bahasa Indonesia dan bahasa Melayu Pasar yang akhirnya menjadi dialek Melayu Jakarta sampai sekarang.

\subsection{Bukti Karya Sastra}

Pijin tidak memiliki tradisi tertulis sehingga tidak ditemukan karya sastra dalam bahasa Melayu Pasar. Bahkan setelah bahasa pijin menjadi kreol, dialek Melayu juga tidak mempunyai tradisi tertulis yang berwujud karya sastra. Hal itu sangat berlainan dengan bahasa Melayu Tinggi. Bahasa tersebut memiliki banyak karya sastra yang benar-benar masih berwujud bahasa Melayu, misalnya novel Siti Nurbaya: Kasih Tak Sampai (karya Marah Rusli) dan Adab dan Sengsara (karya Merari Siegar) yang keduanya dibuat sekitar tahun 1920-an, sebelum dicetusnya Sumpah Pemuda. Bahasa kedua novel tersebut bersifat sangat kemelayumelayuan, tetapi secara linguistis mempunyai kemiripan dengan bahasa Indonesia standar, dan sangat berbeda dengan dialek Melayu. Dengan demikian, jika dirunut secara top down, bahasa Indonesia sangat dekat dengan bahasa Melayu yang digunakan di daerah Sumatra (sekitar Riau), dengan cara melihat perjalanan bentuk linguistik dalam karya sastra mulai angkatan 90-an, 60-an, 33-an, 20-an, juga ke angkatan sebelum Balai Pustaka, yaitu zaman peralihan (Abdullah Bin Abdul Kadir Munsyi), bahkan juga ke zaman sastra lama 
(misalnya cerita Hikayat Si Miskin, Hikayat Pancatantra, dsb.).

Meskipun bahasa Indonesia secara genetis berasal dari bahasa Melayu yang asli (bukan bahasa campuran), bahasa Indonesia sekarang banyak mengalami perkembangan/pemekaran kosakatanya, yaitu "sumbangan" dari bahasa asing dan daerah. Meskipun demikian, "sumbangan" itu bukan campuran, tetapi hanya integrasi bahasa asing ke dalam bahasa Indonesia. Selain, kosakata yang berintegrasi ke dalam bahasa Indonesia, juga sistem morfologinya, tetapi tidak sistem sintaksisnya.

\section{SIMPULAN}

Dengan adanya bukti bandingan bahasa Indonesia secara sinkronis (dengan dialek-dialek Melayu) dan secara diakronis (dengan bahasa Melayu Tinggi) tersebut, dalam penelitian yang telah dilakukan ini dapat dibuktikan bahwa bahasa Indonesia bukan merupakan pijin maupun kreol. Selain itu perlu dibuktikan secara linguistik apakah suatu bahasa merupakan pijin atau bukan, bukan berdasarkan pembuktian secara historis.

\section{UCAPAN TERIMA KASIH}

Peneliti mengucapkan terima kasih kepada redaksi jurnal bahasa \& sastra atas pemuatan artikel hasil penelitian ini.

\section{PUSTAKA RUJUKAN}

Alisyahbana, S. T.(1975). Layar Terkembang (cetakan I, 1937). Jakarta: Balai Pustaka.

$\begin{array}{lr}\text { Perjuangan (1978). } & \text { Dari } \\ \text { Pertumbuhan } & \text { dan } \\ \text { Bahasa }\end{array}$

Indonesia. (cetakan I, 1957). Jakarta: PT Dian Rakyat.

Alwasilah, A. C. (1985). Sosiologi Bahasa. Bandung: Angkasa.

Brakel, L.F. (eds).(1975). Hikayat Muhammad. Koninklijk Instituut Voor Taal-, Landed Volkenkunde, The Hague-Martinus Nijhoff.

Chambert-Loir, H. (ed). (2009). Hikayat Nahkoda Asik. Masup Jakarta, Perpustakaan Nasional Republik Indonesia, Jakarta.

Chaer, A., \& Agusta, L. (1985). Sosiolinguistik (Perkenalan Awal). Jakarta: Rineka Cipta.

Crystal, D.(1992). The Cambrigde Encyclopedia of Language. London: Cambrigde University Press.

Dardjowidjojo, S.(ed). 1996. Bahasa Nasional Kita. Bandung: Penerbit ITB.

Fasold, R. (1990). Sociolinguistics of Language. Cambridge : Basil Blackwell.

Haji Salleh, S.H. (1992). Bustan alSalatin. Dewan Bahasa dan Pustaka, Kementrian Pendidikan Malaysia, Kuala Lumpur.

Kridalaksana, H. (1991). Masa lampau Bahasa Indonesia: Sebuah Bunga Rampai. Yogyakarta: Kanisius.

Mahsun, M.S. (2005). Metode Penelitian Bahasa. Jakarta: PT Raja Grafindo Persada.

Poedjosoedarmo, S. (1978). "Interferensi dan integrasi dalam situasi keanekabahasaan". Pengajaran Bahasa dan Sastra Th. IV, No. 2: 2143. 
Rona. (1999). "Identifikasi Bahasa Melayu Ambon". Makalah. Disajikan dalam Perkuliahan Dialektologi, Program Pascasarjana S2, Universitas Gadjah Mada).

Rusli, M. (1965). Siti Nurbaya (Kasih Tak Sampai). (cetakan ke11). Jakarta: Balai Pustak
Suhardi, B., et al. (1995). Teori dan Metode Sosiolinguistik. Jakarta: Pusat Pembinaan dan Pengembangan Bahasa

Todd, L.(1974). Pidgins and Creoles. London: Routledge.

Wardhaugh, R. (1986). An Introduction to Sociolinguistics. Cambridge: Basil Blackwell. 